http://nv.nltu.edu.ua

https://doi.org/10.15421/40280403

Article received 21.02.2018 p.

Article accepted 26.04.2018 p.

УДК 657.1

${ }^{1}$ Національний лісотехнічний університет України, м. Львів, Україна

${ }^{2}$ Львівський національний університет ім. Івана Франка, м. Львів, Украӥна

\title{
ЛОГІСТИКА ІНВЕСТИЦІЙНИХ ПРОЦЕСІВ ЯК ФАКТОР ЕКОНОМІЧНОГО АНАЛІЗУ
}

Висвітлено підходи до дискурсивного пізнання інвестиційної діяльності в контексті реформування вітчизняної економіки. Конкретизовано дефініції інвестицій та логістики для потреб дослідження розглядуваних феноменів у перехідній економіці. Виділено особливості логістичного потоку. Відповідно до сутності інформаційних та фінансових потоків визначено завдання кожного з елементів логістичної інвестиційної структури. Досліджено питому вагу та значення інвестиційної діяльності поміж іншими видами звичайної діяльності підприємства. Окреслено характерні риси інвестування та специфіку інвестування логістичної сфери. Визначено загальні засади дискурсивного пізнання економічних процесів, на основі яких було вдосконалено методику аналізу ефективності інвестиційних проектів. Аналіз ефективності інвестиційних операцій у кожного з учасників (інвестор, позичальник, ринок (покупець)) дає змогу визначити загальну ефективність в економічній системі. Запропоновано методику логістичного аналізу ефективності інвестиційних проектів. Визначено та обгрунтовано концептуальні підходи до аналізу ефективності інвестиційних проектів на засадах логістики та запропоновано концептуальну схему логістичного аналізу ефективності інвестиційного проекту.

Ключові слова: інвестиції; інвестиційний клімат; методика; економічний розвиток; відтворювальний процес; логістика; логістичний аналіз; інвестиційна логістика.

Вступ. Формування цілей спрямованої інвестиційної діяльності є основною умовою становлення та розвитку будь-якої галузі. Діяльність, що пов'язана з інвестиціями, є важливою детермінантою економічного зростання, яка докорінно змінює економічне, інформаційне і правове середовище функціонування. Характерна риса інвестицій для суб'єктів фінансово-господарської діяльності полягає в тому, що саме інвестиції дають змогу ефективно та успішно забезпечити вирішення різних проблем щодо відтворювального процесу (підприємства, окремих галузей та економіки України загалом), а це залежить від інвестиційного клімату. Активація інвестиційних процесів у відтворювальному процесі підприємства залежить від інвестиційного клімату. Інвестиційна діяльність - це уміння інвестувати (створити сприятливий інвестиційний клімат), і від цього залежить розвиток власного виробництва, вирішення економічних, соціальних та інших проблем, сучасний рівень і потенційний динамізм фінансового та людського капіталів. Для стабільного економічного розвитку української економіки та наближення до європейської інтеграції ефективним інструментом є залучення досвіду в сфері іноземного інвестування країн-членів Свросоюзу.

На сучасному етапі розвитку і реформування економіки в Україні та, враховуючи умови різних світових фінансово-економічних криз, умови забезпечення ефективної діяльності підприємств, забезпечення конкурен- тоспроможності, що характеризується рівнем інвестиційного потенціалу та рівнем інвестиційної діяльності, необхідно виділити роль логістики у цій сфері діяльності. Підприємство, застосовуючи логістику, вирішує питання з оптимізації управління економічними потоками на всіх етапах інвестиційного проекту, що буде позитивно впливати на підвищення ефективності цього проекту загалом. Інвестиційна логістика $є$ процесом управління потоками капіталу та інформації для тривалих незворотних змін у часі, що мають місце серед учасників інвестування за умови оптимізації руху капіталу, діяльності учасників $\mathrm{i}$ досягнення економічного й соціального ефекту (Stanovyshche, n.d.). Як свідчить досвід, логістика (у процесі забезпечення інвестиційного процесу) сприяє виникненню нового інвестиційного продукту з визначеними вартісними та споживчими якостями, в такий спосіб забезпечуючи зниження витрат та підвищення якості.

Аналіз останніх досліджень і публікацій. Значний внесок у розробку теоретичних і методичних питань щодо проблеми покращення інвестиційного клімату, дослідження різних етапів інвестиційного розвитку та ефективності інвестицій зробили такі вітчизняні та зарубіжні вчені: Дж. М. Кейнс, І. Бланк, Я. Крупка, П. Куцик, У. Шарп, Л. Вовк, О. Вовчак, Г. Строкович, Г. Арнаутов, Н. Татаренко, С. Харріс, I. Бондарчук, О. Судакова, О. Чабанюк, Є. Крикавський, Е. Мате, С. Lawren-

\section{Інформація про авторів:}

Гарасим Петро Миколайович, д-р екон. наук, професор, завідувач кафедри обліку і аудиту. Email: garasymp@ukr.net Лобода Наталя Олександрівна, канд. екон. наук, доцент, кафедра обліку та аудиту. Email: loboda.Iviv@gmail.com Цитування за ДСтУ: Гарасим П. М., Лобода Н. О. Логістика інвестиційних процесів як фактор економічного аналізу. Науковий вісник НлтУ України. Серія Економічна. 2018, т. 28, № 4. С. 20-25

Citation APA: Garasym, P. N., \& Loboda, N. O. (2018). Logistics of Investment Processes as Economy Analysis Factor. Scientific Bulletin of UNFU, 28(4), 20-25. https://doi.org/10.15421/40280403 
ce, C. Camerer, R. Thaler, A. Shleifer та ін. Досліджено потенціал як основа логістичної системи фірми в наукових працях із Санкт-Петербурзької школи логістики (А. Долгов, В. Козлов, С. Уваров та ін.). У їхніх працях розглянуто питання щодо визначення пріоритетних напрямів логістики та інвестування, оцінки ефективності реалізації та формування привабливості інвестиційного проекту. У своїх працях науковці досліджують інвестиційну діяльність як складову, що забезпечує виробний процес підприємства, наголошують на необхідності ефективної організації управління рухом інвестиційних потоків. За науковими результатами досліджень вчених, варто все-таки зазначити, що сьогодні в сучасних умовах поставлено нові завдання та комплексний підхід до вирішення проблем, пов'язаних із питанням інвестиційної логістики. Однак це питання залишається дискусійним та неповністю вирішене.

Мета роботи. Ідентифікувати детермінанти логістичної компоненти інвестиційного потенціалу і на основі цього аргументувати використання логістичних принципів та методів в управлінні інвестиційною діяльністю підприємства та розробленні інвестиційних проектів.

Викладення основного матеріалу дослідження. У процесі відображення будь-якого економічного явища під час здійснення економічного аналізу основною $є$ його загальноекономічна характеристика. Відтак важливим $є$ дослідження економічної сутності та умов розвитку інвестиційної діяльності.

Це дослідження необхідно здійснювати, відштовхуючись від визначення економічної суті категорії "інвестиції". Потрібно наголосити, що в літературі немає єдиної думки щодо підходу до тлумачення дефініції "інвестиції". Так, на зазначену обставину звертає увагу у своїй праці Л. С. Вовк, який пропонує визначити поняття інвестицій як "вкладення засобів з метою забезпечення їх збільшення у майбутньому" (Vovk, 2000, p. 5). С. Мочерний трактує інвестиції як "довготермінові вкладення капіталу в різні сфери та галузі народного господарства всередині країни та за ії межами з метою привласнення прибутку" (Vovchak, 2008, p. 20). Г. В. Строкович визначає поняття інвестицій дещо інакше як "вкладення капіталу 3 метою його наступного збільшення або досягнення соціального ефекту", а саму інвестиційну діяльність - як об'єктивну єдність процесів вкладення ресурсів і одержання прибутку або соціального ефекту (Strokovych, 1999, pp. 4-5). Разом із тим, Г. Л. Арнаутов інакше визначає поняття інвестицій - "економічні ресурси, що вилучаються 3 поточного обігу й спрямовуються на формування основних та оборотних коштів суб'єктів господарської діяльності з ме- тою отримання різних вигод" (Arnautov, 2000, p. 6). На думку У. Шарпа, термін "інвестувати" означає "розлучитися" з грошима сьогодні для того, щоб отримати більшу їх суму в майбутньому (Sharp, Aleksander \& Beily, 1999). О. М. Чабанюк зазначає, що методологічні основи формування в бухгалтерському обліку інформації про проведення інвестиції визначено в положеннях стандартів бухгалтерського обліку (Chabaniuk, 2017, p. 15). Досліджуючи всесвітньо відомі фундаментальнотеоретичні праці вчених (І. Бланк, А. Філіпенко, М. Колесник, О. Мертенс), можна зазначити, що зазвичай інвестиції розглядають як фінансові.

В Україні основним показником, що характеризує ринок інвестицій, є великий попит та незначна пропозиція. Як зазначають офіційні джерела, потреба інвестиційних вливань в оновлення основних засобів становить близько 210 млрд дол. Структуру джерел фінансування інвестицій в основний капітал в Україні за 20062017 рр. подано в таблиця.

Головною передумовою надійної економічної системи $\epsilon$ пошук, залучення та стимулювання інвестиційних коштів, спираючись на різні джерела фінансування. За результатами проведеного дослідження, основним джерелом фінансування та розвитку інвестиційної діяльності (у країнах із розвиненою ринковою економікою) $\epsilon$ державні заощадження (переважно це кошти місцевих та державних бюджетів). В Україні ж частка грошових коштів державного та місцевого бюджетів, спрямована в інвестиційну діяльність, у 2017 р. становила 6,6 \%, що менше за 2006 р. на 4,4 \%, тобто держава щорічно зменшує обсяги фінансування (частка грошових коштів державних бюджетів була найбільшою у 2011 р. - 7,5 \%, але 3 кожним роком питома вага грошових коштів державного бюджету скорочувалася і в 2017 р. вже становила $1,5 \%$ ).

Варто зауважити, що основними джерелами інвестиційних ресурсів $€$ :

- власні грошові кошти підприємств та організацій;

- грошові кошти населення під житло;

- кредити банків та фінансових установ;

- грошові кошти іноземних інвесторів;

- інші джерела.

Враховуючи дані, що наведені в таблиці, бачимо, що основним джерелом інвестиційних ресурсів в Україні у період з 2006 по 2017 рр. залишаються власні грошові кошти підприємств та організацій (59,8 та 74,3 \% відповідно).

Таблиця. Структура інвестицій в основний капітал за джерелами фінансування в Украӥні у 2006-2017 рр., \% до загального обсягу

\begin{tabular}{|c|c|c|c|c|c|c|c|c|c|c|c|c|}
\hline \multirow{2}{*}{ Джерело інвестування } & \multicolumn{12}{|c|}{ Рік } \\
\hline & 2006 & 2007 & 2008 & 2009 & 2010 & 2011 & 2012 & 2013 & 2014* & $2015^{*}$ & $2016^{*}$ & $2017 *$ \\
\hline Кошти Держбюджету & 6,5 & 5,6 & 5,0 & 4,4 & 6,3 & 7,5 & 6,3 & 2,5 & 0,7 & 2,4 & 2,8 & 1,5 \\
\hline Кошти місцевого бюджету & 4,5 & 3,9 & 4,2 & 2,7 & 2,9 & 2,9 & 3,2 & 2,8 & 2,6 & 5,0 & 5,3 & 5,1 \\
\hline Власні кошти підприємств & 59,8 & 56,5 & 56,7 & 63,3 & 55,7 & 54,0 & 59,2 & 63,4 & 71,5 & 67,4 & 58,8 & 74,3 \\
\hline Кошти іноземних інвесторів & 3,4 & 3,5 & 3,1 & 4,5 & 2,3 & 2,1 & - & 1,6 & & & & 1,7 \\
\hline Кошти населення під житло & - & 4,5 & 5,0 & 3,6 & 10,7 & 7,2 & 8,3 & 11,2 & 10,5 & 12,0 & 23,5 & 8,9 \\
\hline Кредити банків & 14,3 & 16,6 & 17,3 & 14,2 & 13,7 & 17,9 & 16,1 & 14,8 & 8,8 & 7,3 & 6,3 & 5,2 \\
\hline Інші джерела & 11,5 & 9,4 & 8,7 & 7,3 & 8,4 & 8,4 & 6,9 & 3,7 & 5,9 & 5,9 & 3,3 & 3,3 \\
\hline
\end{tabular}

* Без урахування тимчасово окупованої території Автономної Республіки Крим і м. Севастополя та частини зони проведення антитерористичної операції (авторська розробка) 
Цей вид є найдорожчим джерелом інвестицій, оскільки формується за рахунок перерозподілу прибутку від діяльності такого підприємства та не передбачає наукової та технологічної складової (для країни це означає закритий характер економічного відтворення). Для суб'єкта підприємницької діяльності вигіднішими $\epsilon$ зовнішні інвестиції, що $\epsilon$ теоретично необмеженими, ніж внутрішні, тому сьогодні вітчизняні підприємства використовують дорожчі джерела інвестування, не маючи доступу до зовнішніх джерел фінансування на прийнятних умовах. Цей вид фінансування був зумовлений тим, що бюджетне фінансування зменшується та ускладнюється доступ до таких інвестиційних ресурсів, як кредити. Кошти фінансових установ та банків $€$ доволі дорогим джерелом інвестування, але мають стабільний характер повернення. Відбувається значне скорочення частки капітальних інвестицій за рахунок залучених кредитних коштів у 2006-2017 pp. (14,3 та 5,2 \% відповідно).

Окремо варто зауважити, що грошові кошти іноземних інвесторів $є$ найбільш якісним та перспективним джерелом інвестицій для організації чи підприємства (звичайно за умови, що ці інвестиції не походять із офшорних зон чи є результатом махінацій із метою уникнення оподаткування або відмивання "брудних" коштів), але за умов економічної нестабільності вони, фактично, є одним із нестабільних джерел фінансування інвестиційної діяльності. Так, у 2008 р. грошові кошти іноземних інвесторів становлять 8,8 млрд грн або 3,1 \% від загальної суми джерел фінансування, у 2011 р. - 7,1 млрд грн або 2,1 \%, у 2013 рр. - 4,0 млрд грн або 1,6 \% відповідно. Дослідження підтверджують негативний вплив криз на збільшення інвестиційних ресурсів, тобто з 2008 по 2013 рр. сума коштів іноземних інвесторів зменшилась у два рази або на 4,8 млрд грн.

У період з 2014 по 2015 рр. в економіці України спостерігалося істотне погіршення економічної ситуації (зумовлене насамперед воєнними діями на сході країни). За цей час було втрачено близько 20 \% промислових потужностей, що сприяло скороченню ВВП у 2014 та 2015 рр. на 6,6 та 9,9\% відповідно.

Український уряд (останні чотири роки), щоб стимулювати інвесторів та створити інвестиційні механізми та інструменти стимулювання інвестицій в українську економіку, забезпечував покращення інвестиційного клімату, використовуючи дерегуляцію та лібералізацію (уряд не застосовував ті стимули інвестиційної діяльності, які використовуються у країнах світу з розвиненою економікою).

Така динаміка інвестиційної діяльності, за оцінками експертів-аналітиків, свідчить про неефективну державну політику (гравці на ринку фінансових послуг не мають достатніх інструментів, щоб акумулювати та надійно інвестувати грошові кошти в основний капітал).

Для стабілізації та позитивної динаміки економіки України (така динаміка була в зовнішній торгівлі до воєнних дій на сході країни) необхідні:

- пошук та розвиток нових ринків (за підтримки дипломатичного забезпечення);

- переорієнтація зовнішньоекономічних зв'язків України на альтернативні ринки збуту товарів українських виробників.

А тепер перейдемо до аналізу досліджень становлення логістики як науки.
Крикавський $\mathrm{C}$. трактує логістику як управлінську діяльність потоками запасів сировини, матеріалів, незавершеного виробництва, готової продукції, послуг та фінансів. Наведене тлумачення охоплює поняття діяльності управління, поняття потоків не тільки матеріальних, а й фінансових та інформаційних (Krykavskyi, 2004).

Французькі вчені Д. Тиксьє і Е. Мате зазначають, що логістика $є$ засобом координації попиту (попиту, що запропонований ринком) та пропозиції (реалізація пропозицій, запропонованих підприємством). Тобто роль логістики визначається у знаходженні найоптимальніших (а не тільки припустимих) впливів на об'єкти (враховуючи задані умови функціонування таких об'єктів).

Розглянувши поняття "логістика" у представлених сферах діяльності, ми виявили, що впровадження логістики у сферу інновацій, що є основними показниками активного розвитку фірми, свідчить про доцільне засвоєння грошових коштів, особливо впливає на отриманий кінцевий результат діяльності фірми. В економіці різних країн світу до основних етапів стрімкого запровадження логістики необхідно віднести такі чинники: глобалізація ринків; значний розвиток інформаційнодослідних технологій; зміни у структурі провадження бізнесу тощо. Враховуючи дослідження, які зробили вчені у світі, можна констатувати, що використання науково-обгрунтованих методів логістики знижує витрати на $19 \%$, товарні запаси - на $69 \%$, скорочує на $49 \%$ надходження товару на ринок. В Україні під час ведення бізнесу на виробництво припадає $20 \%$, а на використання логістики - 80 \% відповідно. Враховуючи такий стан справ, українському бізнесу надається поштовх у розвитку якості у сфері управління, оптимізації витрат та прирості прибутку.

У 2005-2007 pp. конкуренція на ринку логістичних послуг України була вкрай слабкою, враховуючи нерозвиненість ринку та невелику кількість наявних операторів. У 2007 р. ситуація почала змінюватися і сьогодні спостерігається посилення конкуренції. Пропорційно зростає рівень вимог до якості сервісу від клієнтів логістичних операторів.

Україна (завдяки впровадженню інфраструктурних інвестиційних проектів під час проведення "Чемпіонату ЄBPO-2012") посіла в рейтингу (LPI - Індекс ефективності логістики, який $є$ основою вимірювання логістичних показників та є основою для дослідження Всесвітнім банком "Підключення до конкуренції: Торгова логістика в глобальній економіці") 66 місце (будучи у 2010 р. на 102-му відповідно).

Отже, розглянемо рівні взаємного впливу між категоріями "логістика" та "інвестиції". Інвестування в основі понесених одноразових витрат стають початковим етапом роботи системи логістики (модернізація та будівництво нових основних фондів, відтак $є$ основною функціональною базою цього комплексу), або на основі доцільно визначеного потоку є основою логістичної компоненти управління. Відтак інвестиції, по-перше, надають структурам логістичного забезпечення можливість здійснювати свої функції постійно та безпечно, а по-друге, самі $є$ основною менеджменту відповідних об'єктів. Ефективність координації досягається етапом впровадження логістики в мережу діяльності фірми (готовність системи діяльності фірми до впровадження ме- 
тодів логістики). Дослідження об'єктів управління логістики можна здійснити на таких рівнях:

- інвестиційна логістика;

- логістика інвестиційного потенціалу;

- інноваційна логістика.

Основою механізму інвестування у будь-який проект $€$ обов'язкове проведення економічної та фінансової оцінки доцільності інвестування (відсутність або небажання проведення такого аналізу під час прийняття остаточного рішення доцільності вкладення інвестицій має значний ступінь ризику, тобто зменшує або унеможливлює його). Проект інвестування запроваджується за умови, якщо інвестор і споживач будуть беззаперечно та на взаємовигідних інтересах виконувати прийняті умови. Інвестиційний проект повинен:

- забезпечити повернення інвестованих коштів за умов отримання прибутку від здійснення господарської діяльності;

- забезпечити господарській діяльності підприємства прибутковість, а це є основою інвестиційної рентабельності на визначеному підприємством рівні;

- забезпечити окупність інвестиційних коштів у встановлений термін.

Отже, в системі інвестиційного управління, об'єктивне оцінювання доцільності (ефективності) інвестування (отримання відповіді щодо термінів повернення інвестованих коштів, забезпечення господарської діяльності підприємства прибутковістю, окупності інвестиційних коштів в установлений термін) постає основним завданням фінансово-економічного аналізу. Враховуючи важливу потреба оцінювання проекту інвестування, здійснимо дослідження наявних теоретико-методологічних основ оцінки їх ефективності. Під час дослідження принципів оцінки інвестиційного проекту можна констатувати, що:

- оцінювання доцільності (ефективності) інвестування потрібно здійснювати на основі порівняння понесених витрат, що пов'язані $з$ інвестуванням, із сумами і термінами їх повернення (на практиці аналіз цього принципу починається 3 порівняння потоків (прямих та зворотних) інвестованого капіталу);

- оцінювання доцільності (ефективності) інвестування потрібно здійснювати, враховуючи витрати (прямі та непрямі) грошових коштів та всі види ресурсів, які задіяні у період здійснення інвестиційного проекту;

- під час оцінювання інвестиційного проекту (а саме - повернення інвестиційного капіталу) необхідно застосувати показник "чистий грошовий потік" (розраховують цей показник як суму чистого прибутку та суму амортизаційних відрахувань за період реалізації інвестиційного проекту). Цей показник можна досліджувати як середньорічний або диференційований за окремими етапами експлуатації цього проекту;

- оцінювання показника "чистий грошовий потік" та понесених інвестиційних витрат необхідно здійснювати, спочатку привівши ці показники до поточної (сучасної) вартості (вибір ставки дисконтування у цьому процесі повинен бути диференційований для різних проектів).

На практиці під час оцінювання реально можливих інвестиційних проектів науковці виділяють два методи:

- перший метод (в основу якого закладено облікову оцінку ефективності інвестицій) здійснює розрахунок показників облікової норми прибутку, термін окупності вкладених інвестицій (при цьому необхідно враховувати, що під час розрахунку фактор часу не приймається, тобто відображення в обліку інвестиційних витрат і доходів здійснюється без їх дисконтування);

- другий метод (в основу якого закладено застосування обов'язкової дисконтованої оцінки ефективності інвестиційного проекту (понесених інвестиційних витрат і доходів), тобто застосовується показник часу). На практиці цей метод набув ширшого застосування, оскільки у сучасному світі умови розвитку ринкової економіки $є$ не передбачуваними та ризикованими.

Процес реалізації проектів інвестування зазвичай пов'язаний з:

- певним інвестиційним ризиком:

- ризик допустимий - ймовірна втрата розрахункового прибутку;

- ризик критичний - ймовірна втрата розрахункового прибутку та прибутку після реалізації інвестиційного проекту;

- ризик катастрофічний - втрата інвестиційного капіталу та банкрутство.

- невизначеністю у сфері господарської діяльності підприємства, що зумовлена об'єктивною неможливістю прогнозувати з належним рівнем допуску показники волатильності ринкової кон'юнктури.

Отже, необхідно проводити попередній аналіз таких показників, як: цінова політика, визначеність термінів інвестування, умови взаємних розрахунків, оцінка витрат (поточних і капітальних) тощо.

Звісно, повна елімінація ризику у сфері господарської діяльності підприємства неможлива, оскільки на цей процес можуть впливати показники, які часто бувають нерегульованими та непередбачуваними. Все, що можна зробити в цій ситуації, це застосовувати різні методи та прийоми, завчасно розробляти альтернативні моделі та передбачувати рейтинги ризикованості інвестиційних проектів із випередженням, задіюючи заходи щодо їх зниження.

Під аналізом інвестиційних потоків підприємства розуміємо дослідження результативних показників їх формування за умови визначення джерел подальшого збільшення у процесі ефективного менеджменту. Під логістичною системою інвестиційних процесів розглядають:

- проектування і використання процесу визначення необхідного інвестиційного капіталу;

- підвищення доцільності (ефективності) цих процесів;

- зниження інвестиційних ризиків шляхом інформування;

- таргетоване використання коштів до чітко визначених інвестиційних пріоритетів та їх логістичної складової.

Здійснення менеджменту логістичною складовою інвестиційної діяльності потребує:

- окреслення етапів в управлінні логістичною системою, іiі підсистемами;

- визначення умов для всіх етапів функціонування логістичної складової;

- розробки в управлінні логістичною системою організаційних структур;

- поєднання етапів і організаційних структур менеджменту логістичної системи.

Під час проведення аналізу інвестиційних проектів потрібно брати до уваги кожного з їі учасників (інвестор, позичальник, ринок (покупець)).

На основі розглянутих вище та вперше запропонованих нами окремих теоретичних положень запропоновано методику логістичного підходу до дискурсивного пізнання інвестиційного процесу (рис.). 


\section{ЦІЛЬ}

Оцінка суспільної значущості проекту

\begin{tabular}{|c|c|}
\hline $\begin{array}{c}\text { БЛОК } 1 \\
\text { Логістичний структурний аналіз ефективності } \\
\text { інвестиційної діяльності } \\
\text { Інвестор: пошук об'єкта інвестування } \\
\text { Позичальник: оцінка потреб об'єкта інвестування } \\
\text { Ринок: оцінка попиту та пропозиції даного продукту }\end{array}$ & \begin{tabular}{l}
\multicolumn{1}{c|}{ БЛОК 2} \\
Оцінка ефективності проекту для кожного учасника \\
Інвестор: оцінка доцільності інвестування \\
Позичальник: визначення умов та чинників \\
залучених коштів \\
Ринок: формування прийнятної цінової політики
\end{tabular} \\
\hline $\begin{array}{l}\text { БЛОК } 3 \\
\text { Визначення логістичних ризиків для всіх учасників } \\
\quad \text { інвестиційного проекту. Управління ризиками } \\
\text { Ідентифікація ризиків; оцінка ступеня вірогідності } \\
\text { фінансових ризиків; оцінка можливих фінансових втрат, } \\
\text { пов язаних з ризиками; формування відповідних резервів, } \\
\text { що призначені для покриття збитків; диверсифікація } \\
\text { ризиків; хеджування; страхування фінансових ризиків }\end{array}$ & \begin{tabular}{l}
\multicolumn{1}{c}{ БЛОК 4} \\
\multicolumn{1}{|c}{ Логістика оптимізації інвестиційних процесів } \\
Інвестор: формування технологій інвестування \\
Позичальник: логістика інвестиційних процесів \\
Ринок: технологія реалізації продукту
\end{tabular} \\
\hline $\begin{array}{c}\text { БЛОК 6 } \\
\text { Економіко-матетатичне моделювання ефективності } \\
\text { інвестиційних процесів } \\
\text { Iнвестор: оцінка ефективності інвестиційної діяльності } \\
\text { Позичальник: розрахунок фінансових потоків. } \\
\text { Формування управлінських рішень на кожний з еитапів } \\
\text { інвестиційного проекту } \\
\text { Ринок: оцінка ефективності реалізації продукту }\end{array}$ & \begin{tabular}{l}
\multicolumn{1}{c}{ БЛОК 5} \\
\multicolumn{1}{c}{ Моніторинг та післяінвестиційний контроль } \\
Інвестор: розробка методології повернення \\
інвестиційного капіталу \\
Позичальник: розробка бізнес--плану інвестиційного \\
проекту \\
Ринок: ринкова стратегія
\end{tabular} \\
\hline
\end{tabular}

Рисунок. Концептуальна схема логістичного підходу

На основі здійсненої розробки визначено загальні засади, на основі яких було вдосконалено методику обчислення ефективності в кожного з учасників (інвестор, позичальник, ринок (покупець)), що дає змогу визначити загальну ефективність в економічній системі.

Також окреслено основні елементи інвестиційних процесів з урахуванням специфіки логістичної сфери:

- враховуючи різні види інвестиційної діяльності, суб'єкти інвестування переслідують різні цілі;

- суб'єкти процесу інвестування повинні певною мірою диференціюватись залежно від шляхів фінансування;

- під час здійснення інвестиційної діяльності необхідно брати до уваги як шляхи фінансування, так і локалізацію об'єктів;

- досягнення максимального показника інвестиційного проекту потребує його логістичне забезпечення.

Висновки. На основі результатів здійсненої розробки необхідно зазначити, що інвестиційна діяльність на сьогодні відіграє надзвичайно важливу роль в економічній системі країни. Визначені пропозиції сприятимуть повному відображенню в економічному аналізі та бухгалтерському обліку процесів інвестування, отримання правдивої інформації щодо отриманих прибутків та понесених витрат у процесі реалізації інвестиційного проекту.

Визначено та обгрунтовано концептуальні парадигми інвестиційного дискурсу економічних процесів на засадах логістики. Концептуальні засади формування логістичної складової підприємства мали б спрямовува- тися на впровадження таргетованих моделей, які будуть модернізувати логістичне навантаження на одиницю облікованої економічної діяльності за ії виробничими та фінансовими результатами.

\section{Перелік використаних джерел}

Arnautov, H. L. (2000). Udoskonalennia orhanizatsiino-ekonomichnoho mekhanizmu investytsiinoi diialnosti v promyslovosti (na prykladi kharchovoi haluzi). Odesa. 19 r. [In Ukrainian].

Chabaniuk, O. M. (2017). Dokumentuvannia ta oblik kapitalnykh investytsii pidpryiemstva. Kompetentsii fakhivtsiv z obliku ta opodatkuvannia $\mathrm{v}$ suchasnykh umovakh vedennia biznesu: materialy $\mathrm{V}$ mizhnarodnoi naukovo-praktychnoi konferentsii "Ekonomika ta menedzhment u kryzovyi period", 8 kvitnia 2017 r., m. Kramatorsk. Vinnytsia: TOV Nilan-LTD, pp. 15-17. [In Ukrainian].

Krykavskyi, I. V. (2004). Lohistyka. Lviv: NU "Lvivska politekhnika". 448 r. [In Ukrainian].

Sharp, U., Aleksander, H., \& Beily, Dzh. (1999). Ynvestytsyy. Moscow: YNFRA-M. 1028 r. [In Russian].

Stanovyshche. (n.d.). Sotsialno-ekonomichne stanovyshche Ukrainy. Retrived from http://www.ukrstat.gov.ua. [In Ukrainian].

Strokovych, H. V. (1999). Vybir stratehii investuvannia pidpryiemstv. Kharkiv. 16 r. [In Ukrainian].

Vovchak, O. D. (2008). Investuvannia. Lviv: Novyi Svit-2000. 544 r. [In Ukrainian].

Vovk, L. S. (2000). Analiz i otsinka investytsiinoi diialnosti pidpryiemstv (na prykladi elektronnoi promyslovosti Ukrainy). Ternopil. 19 r. [In Ukrainian].

\footnotetext{
П. Н. Гарасим ${ }^{1}$, Н. А. Лобода ${ }^{2}$

${ }^{1}$ Национальный лесотехнический университет Украины, г. Львов, Украина 2 Львовский национальный университет им. Ивана Франко, г. Львов, Украина
}

\section{ЛОГИСТИКА ИНВЕСТИЦИОННЫХ ПРОЦЕССОВ КАК ФАКТОР ЭКОНОМИЧЕСКОГО АНАЛИЗА}

Освещены подходы к дискурсивному познанию инвестиционной деятельности в контексте реформирования отечественной экономики. Конкретизированы дефиниции инвестиций и логистики для нужд исследования рассматриваемых феноменов в переходной экономике. Выделены особенности логистического потока. Согласно сущности информационных и финансовых потоков определены задачи каждого из элементов логистической инвестиционной структуры. Исследованы удельный вес и значение инвестиционной деятельности среди других видов обычной деятельности предприятия. Определены характерные черты инвестирования и специфика инвестирования логистической сферы. Установлены общие принципы дискурсивного познания экономических процессов, на основе которых была усовершенствована методика анализа эффективности инвестиционных проектов. Анализ эффективности инвестиционных операций у каждого из участников (инвестор, 
заемщик, рынок (покупатель)) дает возможность определить общую эффективность в экономической системе. Предложена методика логистического анализа эффективности инвестиционных проектов. Определены и обоснованы концептуальные подходы к анализу эффективности инвестиционных проектов на основе логистики и предложена концептуальная схема логистического анализа эффективности инвестиционного проекта.

Ключевые слова: инвестиции; инвестиционный климат; методика; экономическое развитие; процесс воспроизводства; логистика; логистический анализ; инвестиционная логистика.

P. N. Garasym 1 , N. O. Loboda ${ }^{2}$

${ }^{1}$ Ukrainian National Forestry University, Lviv, Ukraine

${ }^{2}$ Ivan Franko National University of Lviv, Lviv, Ukraine

\section{LOGISTICS OF INVESTMENT PROCESSES AS ECONOMY ANALYSIS FACTOR}

The authors have considered urgent issues of development of investment activity in Ukraine. In a stable economic development, investment plays an important role in the implementation of individual and social reproduction. We have investigated the structure of investment into fixed capital by sources of financing in Ukraine, where the main prerequisite for a reliable economic system is to search and attract investments from different sources of financing. The essence of investments and logistics for the needs of economic analysis in the conditions of a transformational economy is specified. The place and role of investment activity among other types of usual activity of enterprises are determined. The features of logistic flow are distinguished. According to the essence of informational and financial flows, the tasks of each of the elements of the logistic investment structure are determined. Logistics infrastructure plays a fundamental role in shaping and developing market relations, ensuring the transition of the economy to the principles of sustainable development. Signs of investment and features that need to be taken into account when investing in the logistics sphere are highlighted. The basic principles of the economic analysis of investment processes are determined, on the basis of which the methodology of the analysis of the evaluation of the effectiveness of investment projects has been improved. The analysis of the efficiency of investment processes in each of the participants (investor, borrower, market (buyer)) enables determining the overall efficiency in the economic system. The methodology of logistic analysis of the efficiency of investment projects is offered. The conceptual approaches to the analysis of the effectiveness of investment projects on the principles of logistics are defined and substantiated. The conceptual scheme of the logistic analysis of the investment project efficiency is proposed.

Keywords: investment; investment climate; methodology; economic development; reproduction process; logistics; logistics analysis; investment logistics. 